\title{
EKSISTENSI PETANI GUREM DI KABUPATEN GRESIK
}

\section{THE EXISTENCE OF GUREM FARMERS IN GRESIK DISTRICT}

\author{
FIRA KHUSNUL ANISAH*, WAHYU SANTOSO, SYARIF IMAM HIDAYAT \\ Fakultas Pertanian, Universitas Pembangunan Nasional "Veteran" Jawa Timur \\ *E-mail : nisnisa8546@gmail.com
}

\begin{abstract}
ABSTRAK
Petani gurem adalah petani yang memiliki lahan kurang dari 0,5 hektar. Keadaan pelaku usaha pertanian tersebut setiap Tahun semakin bertambah jumlahnya dengan tingkat kesejahteraan yang masih rendah. Masih rendahnya taraf kesejahteraan petani terlihat dari hasil sementara Sensus Pertanian (SP) menyatakan bahwarumah tangga petani gurem dengan penguasaan lahan kurang dari 0,5 hektar, baik milik sendiri maupun menyewa. tujuan yang ingin dicapai dalam penelitian ini yaitu Mengidentifikasi eksistensi petani gurem di kabupaten Gresik, Menganalisis faktor - faktor yang mengakibatkan jumlah petani gurem meningkat dengan metodologi yang pertama analisis deskriptif operasional yang akan menjelaskan bagaimana keadaan petani gurem di Kabupaten Gresik, yang kedua yaitu menggunakan analisis regresi linier berganda dengan variabel dummy dua sisi. Data yang digunakan dalam penelitian ini yaitu data sekunder yang diperoleh dari BPS (Badan Pusat Statistika) Kabupaten Gresik.
\end{abstract}

Kata kunci : petani gurem, kabupaten gresik, Kesejahteraan petani

\section{ABSTRACT}

Smallholders are farmers who own less than 0.5 hectares of land. The condition of the agricultural business actors every year is increasing in number with a low level of welfare. The low level of farmer welfare can be seen from the results while the Agricultural Census (SP) stated that smallholder farmers' households with land tenure of less than 0.5 hectares, both owned and rented. The objectives to be achieved in this study are to identify the existence of smallholders in Gresik Regency, to analyze the factors that cause the number of smallholders to increase with the first methodology an operational descriptive analysis that will explain how the condition of smallholders in Gresik Regency is, the second is to use regression analysis. multiple linear with a two-sided dummy variable. The data used in this study is secondary data obtained from BPS (Central Bureau of Statistics) Gresik Regency.

Keywords: small farmers, Gresik district, farmer welfare

\section{PENDAHULUAN}

Indonesia merupakan Negara yang tropis dengan luas lahan yang sangat luas dan keanekaragaman hayati yang sangat beragam dan kaya akan penanaman jenis palawija. Iklim Indonesia memungkinkan untuk tumbuh suburnya berbagai jenis tanaman, buahbuahan, dan palawija tersebut. Indonesia dikenal sebagai Negara agraris artinya pertanian memegang peranan penting dari seluruh perekonomian nasional. Hal ini dapat ditunjukkan banyaknya penduduk yang hidup dan bekerja pada sektor pertanian. Sektor pertanian merupakan sektor yang mempunyai peranan strategis dalam pembangunan ekonomi nasional. Pertanian mempunyai 
kontribusi penting baik terhadap perekonomian maupun terhadap pemenuhan kebutuhan pokok masyarakat, apalagi dengan semakin meningkatnya jumlah penduduk yang berarti bahwa kebutuhan akan pangan juga semakin meningkat. Maka dari itu pemerintah harus lebih serius lagi dalam upaya penyelesaian masalah pertanian demi terwujudnya pembangunan pertanian yang lebih maju demi tercapainya kesejahteraan masyarakat khususnya petani. (Irianto,2013) Pertanian adalah kegiatan pemanaatan sumber daya hayati yang dilakukan manusia untuk menghasilkan bahan pangan,bahan baku atau industri,sumber energi serta mengelola lingkungan hidupnya. Sebagian besar penduduk dunia bermata pencaharian dalam lingkup pertanian,namun pertanian hanya menyumbang $4 \%$ dari produk domestik bruto dunia. Indonesia dikenal sebagai negara agraris yang berarti negara yang mengandalkan sektor pertanian baik sebagai sumber mata pencaharian maupun sebagai penopang pembangunan(Hanafi,2010).

Sektor petanian merupakan salah satu sektor yang mempunyai kontribusi penting dalam pembangunan nasional melalui perannanya. Dalam pembentukan
PDB,penyerapan tenaga kerja,sumber pendapatan masyarakat serta dalam memproduksi pertanian untuk penyediaan pangan,pakan,bahan baku industri dan ekspor Pertanian merupakan salah satu sektor kehidupan masyarakat Indonesia. Hal ini dapat dilihat dari mayoritas penduduk yang bermata pencaharian sebagai petani dan didukung dengan kondisi kesuburan tanah dan iklim tropis yang dapat menumbuhkan berbagai jenis tanaman.

Pertanian di Indonesia terbagi menjadi dua yaitu pertanian tanaman pangan dan pertanian tanaman keras. Seperti tanaman kakao,sawit dan lainnya sedangkan pertanian tanaman pangan seperti jagung,padi,sayur mayur dan buah-buahan dan lainnya. Menyempitnya lahan pertanian merupakan masalah serius yang dihadapi oleh para petani. Hal ini terjadi karena semakin luas terjadi konversi lahan sawah untuk penggunaan lain seperti perkebunan sawit. Di tengah berlangsungnya pembangunan ekonomi yang tidak lagi menempatkan sektor pertanian pangan sebagai fondasi ekonomi nasional, berbagai persoalan mendasar masih dihadapi penduduk pedesaan yang mayoritas bekerja di sektor pertanian. Produktivitas tenaga kerja yang rendah, sempitnya lahan 
garapan, terjadinya alih fungsi lahan, meningkatnya penganguran, dan lainnya menyebabkan kesejahteraan penduduk pedesaan tidak kurung membaik. Minimnya kemampuan penguasaan lahan ini juga menjadikan para petani sebagai petani gurem dan hampir semua petani di Indonesia ini adalah petani gurem.

Petani gurem adalah petani yang memiliki lahan kurang dari 0,5 hektar. Keadaan pelaku usaha pertanian tersebut setiap Tahun semakin bertambah jumlahnya dengan tingkat kesejahteraan yang masih rendah. Masih rendahnya taraf kesejahteraan petani terlihat dari serta dalam memproduksi pertanian untuk penyediaan pangan,pakan,bahan baku industri dan ekspor

Pertanian merupakan salah satu sektor kehidupan masyarakat Indonesia.Halini dapat dilihat dari mayoritas penduduk yang bermata pencaharian sebagai petani dan didukung dengan kondisi kesuburan tanah dan iklim tropis yang dapat menumbuhkan berbagai jenis tanaman. Pertanian di Indonesia terbagi menjadi dua yaitu pertanian tanaman pangan dan pertanian tanaman keras. Seperti tanaman kakao,sawit dan lainnya sedangkan pertanian tanaman pangan seperti jagung,padi,sayur mayur dan buahbuahan dan lainnya.

Menyempitnya lahan pertanian merupakan masalah serius yang dihadapi oleh para petani. Hal ini terjadi karena semakin luas terjadi konversi lahan sawah untuk penggunaan lain seperti perkebunan sawit. Di tengah berlangsungnya pembangunan ekonomi yang tidak lagi menempatkan sektor pertanian pangan sebagai fondasi ekonomi nasional, berbagai persoalan mendasar masih dihadapi penduduk pedesaan yang mayoritas bekerja di sektor pertanian. Produktivitas tenaga kerja yang rendah, sempitnya lahan garapan, terjadinya alih fungsi lahan, meningkatnya penganguran, dan lainnya menyebabkan kesejahteraan penduduk pedesaan tidak kurung membaik. Minimnya kemampuan penguasaan lahan ini juga menjadikan para petani sebagai petani gurem dan hampir semua petani di Indonesia ini adalah petani gurem.

Petani gurem adalah petani yang memiliki lahan kurang dari 0,5 hektar. Keadaan pelaku usaha pertanian tersebut setiap Tahun semakin bertambah jumlahnya dengan tingkat kesejahteraan yang masih rendah. Masih rendahnya taraf kesejahteraan petani terlihat dari hasil sementara Sensus Pertanian (SP) 
menyatakan bahwarumah tangga petani gurem dengan penguasaan lahan kurang dari 0,5 hektar, baik milik sendiri maupun menyewa, pada Tahun 1993 hanya $51,9 \%$ dari 20,8 juta rumah tangga petani saat itu. Tahun 2003, Tahunkemudian, porsi petani gurem 53,9\% dari total rumah tangga petani. Tahun 2008, persentase petani gurem sekitar 55,1 (Bappenas, 2013).

Penyempitan lahan juga mengakibatkan petani gurem harus menyewa lahan dari pemilik lahan pertanian supaya dapat mengolah lahan pertanian lebih luas lagi atau menjadi buruh tani. Petani gurem tidak dapat memenuhi kebutuhan hidupnya atau meningkatkan produksi pertaniannya apabila tidak memperluas lahan pertanian mereka dengan menyewa lahan dari pemiliki lahan atau dengan memilih pekerjaan di luar pertanian. Penyempitan lahan persawahan ini juga menyebabkan banyaknya masyarakat pedesaan yang menjadi pekerja sebagai buruh tani. Dengan menjadi buruh tani, upah yang didapatkan dapat menjadi tambahan untuk memenuhi kelangsungan hidup selain dengan mengolah lahan pribadinya. Para buruh tani ini juga ada yang memang bermatapencaharian sebagai buruh tani yang mengharapkan upah dari pekerjaan pertanian sebagai penghasilannya tanpa memiliki lahan sedikit pun. Para buruh tani mengerjakan pekerjaan mulai dari menanam padi, merawat tanaman padi, dan memanen hasil. Adanya kontak langsung petani dan buruh tani dalam suatu masyarakat pertanian menimbulkan hubungan antara petani dan buruh tanibaik itu hubungan kerja yang ditandai dengan adanya hubungan pertukaran maupun hubungan sosial Sektor pertanian merupakan sektor yang berperan besar dalam pembangunan nasional. Berdasarkan data Badan Pusat Statistik dalam Laporan Tahunan Kementerian Pertanian (2016), nilai Produk Domestik Bruto (PDB) sektor pertanian dalam arti luas untuk periode 2014-2016 menunjukkan tren yang selalu meningkat dari Tahun ke Tahun. Nilai PDB sektor pertanian atas dasar harga berlaku pada Tahun 2014 yakni sebesar 1.409.655,70 kemudian meningkat menjadi 1.555.746,9 pada Tahun 2015, dan mencapai angka 1.668.997,8 pada Tahun 2016. Sektor pertanian memberikan kontribusi positif terhadap pertumbuhan ekonomi nasional. Peningkatan kontribusi sektor 4 pertanian dalam pertumbuhan ekonomi nasional merupakan upaya yang dilakukan pemerintah untuk meningkatkan 
Berdasarkan data yang bersumber dari BPS diperoleh bagan petani gurem di Indonesia sebagai berikut :

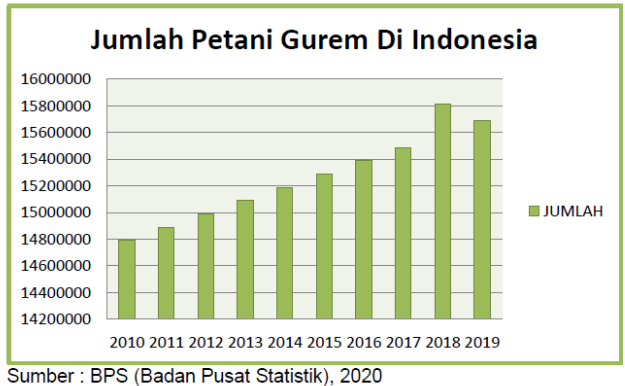

Berdasarkan bagan diatas dapat dikatakan bahwa jumlah petani gurem di donesia sediri meningkat dan hal itu menandakan kurangnya kesejahteraan petani indonesia. Struktur masyarakat pertanian di desa ini terdapat tiga lapisan sosial yang terdiri dari lapisan atas (petani pemilik atau pemilik lahan yang tidak mengolah lahannya), lapisan menengah (petani pemilik sekaligus penggarap) dan buruh tani (buruh tani yang memilikis sedikit lahan dan sama sekali tidak memiliki lahan). Para petani di desa ini sebagian besar petani yang menyewa lahan dari pemilik lahan sawah yang tidak dikelolahnya untuk memperluas lahan pertaniannya. Buruh tani di desa ini terdapat tiga kelompok buruh tani berdasarkan hubungan yang terjalin dengan petani pemilik yaitu buruh tani tetap (terikat dengan petani pemilik dan tidak bebas bekerja di lahan pertaniaan siapa saja), buruh tani langganan (buruh petani yang dipakai secara tetap apabila petani pemilik membutuhkannya untuk mengolah lahannya namun tidak terikat dan dapat bekerja di tempat lain), dan buruh tani bebas (tidak terikat dengan petani pemilik dan bebas bekerja di lahan pertanian siapa saja).

Sehingga permasalahan tersebut menjadi permasalahan yang harus dipecahkan maka dari itu tujuan penelitian ini menganalisis eksistensi petani gurem di kabupaten Gresik dan juga menganalisis faktor faktor yang mempengaruhi eksistensi petani gurem di kabupaten Gresik.

\section{TINJAUAN PUSATAKA}

\section{Eksistensi}

Menurut Sjafirah(2016),eksistensi di artikan sebagai keberadaan. Dimana keberadaan yang di maksud adalah adanya pengaruh atas ada atau tidak adanya kita. Eksistensi ini perlu “diberikan" orang lain kepada kita, karena dengan adanya respon dari orang di sekeliling kita ini membuktikan bahwa keberadaan atau kita diakui. Masalah keperluan akan nilai eksistensi ini sangat penting, karena ini merupakan pembuktian akan hasil kerja atau performa di dalam suatu lingkungan. Dalam Kamus Umum Bahasa Indonesia, dijelaskan bahwa: "Eksistensi artinya 
keberadaan, keadaan, adanya" Selain itu dalam Kamus Besar Bahasa Indonesia dikemukakan bahwa: "Eksistensi; kebendaan, adanya" Eksistensi bisa juga dikenal dengan satu kata yaitu keberadaan.

\section{Petani Gurem}

Menurut Rodjak, (2006) petani sebagai unsur usaha tani memegang peranan yang penting dalam pemeliharaan tanaman atau ternak agar dapat tumbuh dengan baik, ia berperan sebagai pengelola usaha tani. Petani sebagai pengelola usaha tani berarti ia harus mengambil berbagai keputusan di dalam memanfaatkan lahan yang dimiliki atau disewa dari petani lainnya untuk kesejahteraan hidup keluarganya. Petani yang dimaksud dalam hal ini adalah orang yang bercocok tanam hasil bumi atau memelihara ternak dengan tujuan untuk memperoleh kehidupan dari kegiatan itu. Apabila ada orang yang mengaku petani yang menyimpang dari pengertian tersebut, dapat dikatakan bukan petani.

\section{Analisis Regresi Linier Berganda}

Analisis regresi (regression analysis) merupakan suatu teknik untuk membangun persamaan dan menggunakan persamaan tersebut untuk membuat perkiraan (prediction). Dengan demikian, analisis regresi sering disebut sebagai analisis prediksi. Dikatakan prediksi karena nilai prediksi tidak selalu tepat dengan nilai riilnya. Semakin kecil tingkat penyimpangan antara nilai prediksi dengan nilai riilnya, maka semakin tepat persamaan regresi yang bentuk. Hal ini dapat didefinisikan bahwa analisa regresi adalah metode statistika yang digunakan untuk menentukan kemungkinan bentuk hubungan antara variabel-variabel dengan tujuan pokok dalam penggunaan metode untuk meramalkan atau memperkirakan nilai dari suatu variabel lain yang diketahui. Ada dua jenis Persamaan Regresi Linier, yaitu analisis regresi linier sederhana dan analisis regresi linier berganda. (Sugiyono, 2017)

\section{Hipotesis}

Berdasarkan teori dan tinjauan pustaka yang telah dijelaskan, terdapat hipotesis dari penelitian ini yaitu :

1. Variabel luas lahan (X1), Harga Komoditas (X2),Umur petani (X3), Pendidikan (X4), Jumlah Anggota Keluarga (X5), mempengaruhi secara signifikan terhadap variabel $\mathrm{Y}$ yaitub jumlah petani gurem di kabupaten Gresik. 


\section{METODE PENELITIAN}

Penelitian ini penulis menggunaka $\mathrm{n}$ obyek penelitian yaitu petani gurem di kabupaten Gresik dan menggunakan data nasional yang diambil dari BPS (Badan Pusat Statistik) dengan jenis penelitian korelasional.Korelasional Jenis penelitian korelasional merupakan penelitian yang bertujuan untuk menentukan hubungan antara dua variabel atau lebih. Pada umumnya, penelitian ini membutuhkan data variabelnya sendiri sehingga penelitian ini memerlukan kegiatan pengumpulan data. Dengan data yang sudah dikumpulkan, dapat diambil sebuah kesimpulan antara hubungan variabel-variabel yang ada.

Data sekunder diperoleh dari BPS (Badan Pusat Statistik) dan juga dari instansi terkait. data sekunder juga diperoleh dari penelusuran kepustakaan, internet dan literatur lain yang berhubungan dengan penelitian Beberapa metode yang digunakan dalam pengumpulan data yakni dengan studi literatur.

Analisis regresi linier berganda digunakan untuk mengetahui seberapa besar pengaruh hubungan

1. Luas lahan (X1)

2. Harga komoditas padi (X2)

3. Umur petani (X3) terdiri dari 3 kategori yaitu 15-24,25-54,55-65.
4. Pendidikan (X4) Terdiri dari 3 kategori yaitu SD,SMP,SMA.

5. Jumlah Anggota keluarga (X5) terdiri dari 3 kategori yaitu $<3,3-5,>5$ terhadap variabel dependen Jumlah petani gurem (Y) Persamaan regresi yang dipakai adalah sebagai berikut (Sugiyono,2014) :

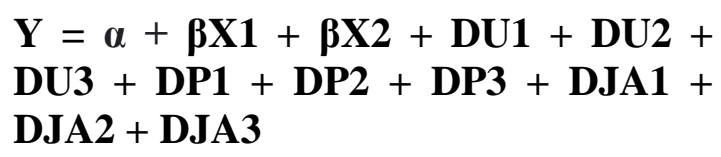

Untuk menguji Hipotsis penelitian:

Uji Statistik F Uji F digunakan untuk menguji dan mengetahui bagaimana pengaruh dari semua variabel bebas secara bersama - sama terhadap variabel terikat di dalam suatu penelitian, dan untuk menguji apakah model regresi yang telah digunakan mempunyai pengaruh yang signifikan atau non signifikan.

\section{HASIL DAN PEMBAHASAN}

\section{Gambaran Umum Kabupaten Gresik}

Secara geografis, Kabupaten Gresik diapit oleh dua wilayah Kabupaten dan satu kota. Dalam kebijaksanaan perwilayaan Jawa Timur, Kabupaten Gresik termasuk dalam wilayah satuan wilayah pembangunan Gerbangkertosusila. Posisi geografis, wilayah Kabupaten Gresik terletak antara $112^{\circ}$ sampai $113^{\circ}$ Bujur Timur dan 
sampai $7^{\circ}$ sampai $8^{\circ}$ Lintang Selatan. Kabupaten Gresik mempunyai wilayah kepulauan, yaitu Pulau Bawean dan beberapa pulau kecil di sekitarnya. Luas wilayah Gresik seluruhnya 1.191,25 Km2, terdiri dari 993,83 Km2 luas wilayah daratan ditambah sekitar 197,42 Km2 luas Pulau Bawean. Sedangkan luas wilayah perairan adalah $5.773,80 \mathrm{Km} 2$ yang sangat potensial 'dari subsektor perikanan laut. Hampir sepertiga bagian dari wilayah Kabupaten Gresik merupakan daerah pesisir pantani, yaitu sepanjang $140 \mathrm{Km}$ meliputi Kecamatan Kebomas, Gresik, Manyar, Bungah, Ujungpangkah, Sidayu dan Panceng, serta Kecamatan Tambak dan Sangkapura yang berada di Pulau Bawean. Kabupaten Gresik merupakan dataran rendah dengan ketinggian 2 sampai 12 meter diatas permukaan air laut kecuali Kecamatan Panceng yang mempunyai ketinggian 25 meter diatas permukaan air laut. Sedangkan wilayah administrasi pemerintahan, Kabupaten Gresik terdiri dari 18 Kecamatan, 26 Kelurahan, 330 Desa,dan 360 Dusun, 1792 RW (Rukun Warga) dan 5101 RT(Rukun Tetangga). (Profil Investasi Kabupaten Gresik, Tahun 2012) .

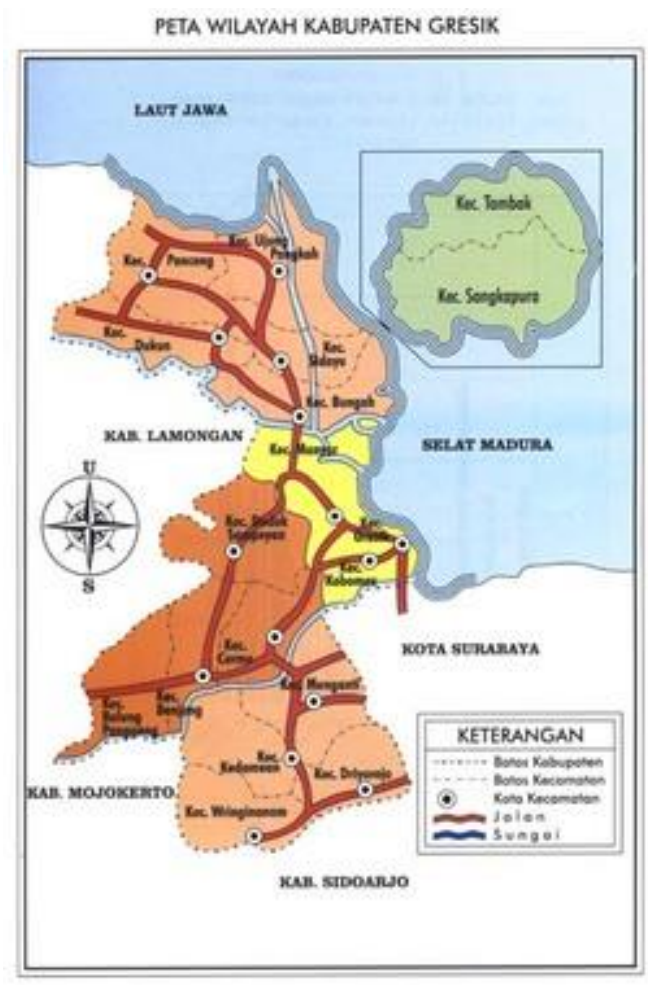

Hal itu karena sektor pertanian mampu memenuhi keutuhan bahan pokok seperti padi dan jagung. Namun dengan adanya alih fungsi lahan pertanian ke non-pertanian mengakibatkan sektor pertanian kedepannya terancam. Hal itu dapat kita lihat sekarang dengan semakin banyaknya lahan pertanian yang semestinya masih bisa dimanfaatkan karena lahan tersebut masih produktif semakin banyak beralih ke lahan nonpertanian seperti perumahan, pertokoan dan industri (Nanda, 2016)

\section{Eksistensi Petani Gurem}

Berdasarkan situs resmi Kabupaten Gresik dikatakan bahwa 
Kabupaten Gresik surplus padi sebesar 129 ribu ton, hal tersebut belum sesuai dengan target produksi yang ditetapkan oleh pemerintah sebesar 382 ribu ton. Penyebab menurunnya produksi pangan di Kabupaten Gresik dikarenakan banyaknya lahan pertanian yang beralih fungsi menjadi industri. Beralihnya fungsi lahan pertanian menjadi industri menyebabkan berkurangnya areal lahan pertanian yang ada di Kabupaten Gresik. Dari data sensus dapat diketahui luas lahan pertanian di Kabupaten Gresik sebesar 36.000 hektar sekarang menjadi 10.000 hektar.

Penyempitan lahan pertanian seluas 26.000 hektar membuat para petani harus bekerja lebih ekstra keras lagi untuk memenuhi kebutuhan pangan. Penyempitan lahan pertanian tersebut terjadi karena ahan pertanian yang ada telah berubah menjadi kawasan industri. Salah satu daerah di Kabupaten Gresik yang pada mulanya merupakan daerah pertanian kemudian menjadi industri adalah Kecamatan Bungah. 5 Dari data sensus pertanian yang dikeluarkan oleh BPS Kabupaten Gresik pada tahun 2013 dapat diketahui bahwa jumlah usaha pertanian mengalami banyak penurunan. Pada sensus tahun 2003 usaha pertanian sebanyak 133.624 sedangkan pada tahun
2013 menjadi 102.330, jika dirata-rata setiap tahunnya mengalami penurunan sebesar 2.34 persen per tahun.6 Menurunnya lahan pertanian yang ada terjadi karena pembangunan industri yang semakin pesat di Kabupaten Gresik. Kecamatan Bungah merupakan wilayah yang memiliki lahan pertanian yang cukup luas. Di samping itu pula alasan wilayah tersebut sangat cocok untuk didirikan pabrik adalah karena cukup strategis dan merupakan wilayah pantura. Selain itu juga di wilayah ini akan dibangun pelabuhan internasional. Pembangunan pelabuhan internasional membawah efek domino munculnya pembangunan pabrik-pabrik di sekitar pelabuhan tersebut. Hal ini membuat para investor yang ingin menanamkan modal di Kecamatan Bungah semakin banyak. Pada mulanya para petani enggan menjual tanah mereka, tetapi setelah harga lahan pertanian melambung tinggi membuat para petani tergiur untuk menjualnya. Selain itu juga ditambah dengan melangitnya pembayaran Pajak Bumi dan Bangunan (PBB) di Kabupaten Gresik membuat petani merasa terbebani dengan pembayaran tersebut, mengingat hasil jual yang diperoleh dari produksi padi tidak seberapa. Namun ada beberapa dari petani yang tidak mau menjual lahan 
mereka, karena merasa apabila menjual lahan maka akan banyak pabrik yang didirikan disekitar lokasi tempat tinggal. Hal ini sangat berdampak pada kondisi lingkungan yang ada dan juga tidak akan ada lagi produktifitas padi karena pencemaran limbah pabrik.

Mereka berusaha untuk mempertahankan lahan pertanian demi anak cucu di masa depan. Jika lahan pertanian sudah tidak ada, maka apa yang akan dimakan di masa depan nanti. Dalam kondisi seperti ini, pihak Pemerintah Kabupaten (Pemkab) Gresik justru tidak melakukan upaya untuk melindungi lahan pertanian yang ada di Kecamatan Bungah. Namun dari pihak pemerintah malah memberikan bantuan kepada para petani yang sudah menjual lahan pertaniannya dengan bantuan sembako. Padahal sebelum petani menjual lahan pertaniannya, mereka tidak pernah mendapat bantuan berupa sembako dari Pemkab Gresik.

Petani gurem menghadapi risiko dari berbagai sumber. Hal ini membuat petani gurem seperti terikat dan tidak mampu mengembangkan hasil pertaniannya karena terbatasnya modal, tingginya bunga yang dibayarkan untuk pinjaman, risiko gagal bayar, dan perilaku tengkulak. Alhasil, secara makro, hal ini dapat menyebabkan perlambatan pertumbuhan produksi pertanian, orangorang banyak yang tidak mau berusaha di pertanian, sehingga terjadi kondisi seperti saat ini di mana impor tanaman pangan di Indonesia cukup tinggi.

Kondisi ini terjadi karena minimnya intervensi pemerintah dalam bidang pertanian. Selain itu, kondisi ini sangat merugikan petani gurem karena berproduksi dengan ketidakpastian yang besar, tetapi mendapat keuntungan yang kecil dari tengkulak. Masalah alih fungsi lahan juga terus terjadi jika petani gurem tidak memiliki keahlian lain akan menyulitkan perekonomian mereka.

\section{Faktor Faktor Yang Mempengaruhi} Eksistensi Petani Gurem

Pertanian merupakan aktivitas ekonomi dunia yang paling penting, dimana pada prakteknya kegiatan ini menggunakan sepertiga dari permukaan bumi dan terdapat sekitar $45 \%$ dari seluruh jumlah penduduk dunia yang bekerja dan terlibat dengan aktivitas pertanian. Pertanian tidak lagi boleh dipandang sebelah mata bagi kehidupan manusia di muka bumi apabila manusia yang semakin ramai dan mempunyai berbagai kebutuhan. Berbeda dengan masyarakat modern yang jumlahnya cukup besar, aktivitas pertanian yang 
baik dan produktif menjadi penting untuk menghasilkan sumber makanan yang banyak. Eksistensi petani merupakan suatu keadaan dimana petani tetap melakukan kegiatan pertanian dalam kondisi apapun. Dalam hal ini eksistensi merupakan kegiatan pertanian yang tetap ada dan berlangsung sampai sekarang.

ANOVA $^{\mathrm{a}}$

\begin{tabular}{|ll|r|c|r|r|c|}
\hline \multicolumn{1}{|c|}{ Model } & Sum of Squares & df & Mean Square & F & Sig. \\
\hline 1 & Regression & 77447341,756 & 5 & 15489468,351 & 15,669 &, $010^{\mathrm{b}}$ \\
& Residual & 3954118,244 & 4 & 988529,561 & & \\
Total & 81401460,000 & 9 & & & \\
\hline
\end{tabular}

Dari hasil uji $F$ diatas menunjukkan bahwa nilai sig sebsar 0,010 yang lebih kecil dari 0,05 maka seluruh variabel independen secara bersama sama atau simultan berpengaruh terhadap variabel dependen

\section{Coefficients $^{\mathrm{a}}$}

\begin{tabular}{|c|c|c|c|c|c|c|}
\hline & \multirow[t]{2}{*}{ Model } & \multicolumn{2}{|c|}{$\begin{array}{c}\text { Unstandardized } \\
\text { Coefficients } \\
\end{array}$} & \multirow{2}{*}{$\begin{array}{c}\text { Standardized } \\
\text { Coefficients } \\
\text { Beta } \\
\end{array}$} & \multirow[t]{2}{*}{$\mathrm{t}$} & \multirow[t]{2}{*}{ Sig. } \\
\hline & & $\mathrm{B}$ & Std. Error & & & \\
\hline \multirow[t]{11}{*}{1} & (Constant) & $-19114,674$ & 25119,118 & &,- 761 & ,586 \\
\hline & LUAS LAHAN & $-6,690$ & 1,393 &,- 863 & $-4,801$ & ,009 \\
\hline & $\begin{array}{l}\text { HARGA } \\
\text { KOMODITAS }\end{array}$ & $-4,136$ & 3,379 &,- 584 & $-1,224$ & ,030 \\
\hline & UMUR 15-24 & $-38,297$ & 82,824 &,- 323 &,- 462 & ,724 \\
\hline & UMUR 55-65 & 5,450 &, 717 & 1,733 & 7,606 & ,002 \\
\hline & SD & $-4,136$ & 3,379 &,- 584 & $-1,224$ & ,030 \\
\hline & SMP & 7,928 & 11,278 &, 590 &, 703 & ,610 \\
\hline & SMA & $-26,456$ & 26,562 &,- 445 &,- 996 &, 501 \\
\hline & $<3$ & 1,125 & 5,475 &, 108 & ,205 &, 871 \\
\hline & $3-5$ & $-6,690$ & 1,393 &,- 863 & $-4,801$ & ,009 \\
\hline & $>5$ & ,009 & ,052 &, 054 &, 166 & ,895 \\
\hline
\end{tabular}

Dari hasil uji $\mathrm{T}$ diatas menunjukkan bahwa pada variabel luas lahan memiliki t hitung $-4,801$ dan nilai sig sebesar 0,009 maka variabel luas lahan berpengaruh terhadap jumlah petani gurem. Variabel harga komoditas dengan nilai $\mathrm{t}$ sebesar -1,224 dengan sig
0,30 maka variabel harga komoditas mempengaruhi jumlah petani gurem. Variabel umur 55-56 memiliki nilai $\mathrm{t}$ sebesar 7,606 dan sig 0,002 maka variabel umur 55-65 mempengaruhi jumlah petani gurem. Variabel pendidikan SD memiliki nilai t sebesar - 
1,224 dengan sig 0,30 artinya variabel pendidikan SD memiliki pengaruh terhadap jumlah petani gurem. Variabel jumlah anggota keluarga 3-5 memiliki nilai $\mathrm{t}$ sebesar $-4,801$ dan sig sebesar 0,009 artinya variabel jumlah anggota keluarga 3-5 orang memiliki pengaruh terhadap jumlah petani gurem

\section{KESIMPULAN DAN SARAN}

\section{Kesimpulan}

Berdasarkan hasil penelitian yang dilakukan yaitu :

1. Eksistensi petani gurem di Kabupaten Gresik masih terbukti ada dan masih berlanjut kehidupannya walaupun ditengah pandemi petani gurem tetap melakukan kegiatan pertanian. Petani gurem di kabupaten Gresik mayoritas pendidikan SD dan di usia yang tua yaitu 55-65 tahun hal ini yang menjadikan kegureman petani semakin berlanjut kesejahteraan petani pun kurang atau dikatakan dibawah standart

2. Faktor faktor yang mempengaruhi jumlah petani gurem di Kabupaten Gresik yaitu faktor luas lahan,harga komoditas, pendidikan (SD), usia (55-65 tahun) dan jumlah anggota keluarga (3-5 anggota).

\section{Saran}

Pemerintah harus melakukan langkah yang tepat untuk mengangkat kesejahteraan petani gurem di Kabupaten Gresik dan juga pemerintah harus tetap menjaga eksistensi petani Gurem untuk kelangsungan kegiatan pertanian di kabupaten Gresik.

\section{DAFTAR PUSTAKA}

Abidin, Zainal. 2007. Analisis Eksistensial. Jakarta: PT. Raja Grafindo Persad

Badan Pusat Statistik. 2011. Petani gurem Jawa timur 2011. BPS: Jawa Timur

Bappenas. 2013. Perangkat Analisis untuk Perencanaan.

Dewa Ketut Sadra Swastika, 2011 membangun kemandirian dan kedaulatan pangan untuk mengentaskan petani dari kemiskinan Pusat Sosial Ekonomi dan Kebijakan Pertanian

Fahrudin, Adi. (2012). Pengantar Kesejahteraan Sosial. Bandung: Refika.

Ghozali, Imam. 2011. Aplikasi Analisis Multivariate dengan Program IBM SPSS 19 Edisi 5. Semarang: Badan Penerbit Universitas Diponegoro

Hanifah, Abu. 2010. Toleransi Dalam Mayarakat Plural Memperkua Ketahanan Sosial. Laporan Penelitian: Puslitbang Kesos 
Harvey, Friska Indira Wardani., Januar, Jani., dan Kusmiati, Ati,. 2009. Trend produksi dan prospek pengembangan komoditas buah naga di kabupaten jember.

Hendayana, R. 2001. Analisis Faktor Faktor Yang Mempengaruhi Nilai Tukar Petani. Pusat Penelitian dan Pengembangan Sosial Ekonomi Pertanian, Badan Penelitian dan Pengembangan Pertanian. Bogor.

Ika Nurfu'adah 2017 faktor yang mempengaruhi eksistensi petani gurem di bantaran sungai brantas kecamatan kesamben kabupaten jombang

Karmiati. et. all. 2016. Strategi Pengembangan Agro Industri Gula Tumbu di Kabupaten Kudus. Jurnal Litbang Provinsi Jawa Tengah. Vol. 14 Nomor 1. Semarang: Fakultas Peternakan dan Pertanian Universitas Diponegoro.

Masyhuri, Zainuddin $\quad$ M. 2008. Metodologi Penelitian, Pendekatan Praktis dan Aplikatif. Bandung: Refika Aditama.

Maulana, Razi. 2008. Hubungan Karakterisrik Wanita Usia Produktif dengan Premenstrual Syndrome di Poli Obstetri dan Ginekologi BPK-RSUD dr.Zainoel Abidin Banda Aceh.
(Penelitian di Poli Obstetri dan Ginekologi BPK-RSUD dr.Zainoel Abidin Banda Aceh, on-line)

Milligan, S., Fabian, A., Coope, P. C., \& Errington. (2006). Family wellbeing indicators from the 19812001. New Zealand Censuses, Statistics New Zealand, Univ. of Auckland and Univ. of Otago.

Ndraningsih, S.K, dkk. 2010. Kinerja Penyuluh Dari Perspektif Petani Dan Eksistensi Penyuluh Swadaya Sebagai Pendamping Penyuluh Pertanian. Jurnal Analisis KebijakanPertanian. Volume 8, Nomor 4. 60

Nuryah Asri Sjafirah Ditha Prasanti 2016 penggunaan media komunikasi dalam eksistensi budaya lokal bagi komunitas tanah aksara studi deskriptif kualitatif tentang penggunaan media komunikasi dalam eksistensi budaya lokal bagi komunitas tanah aksara di bandung Jurnal Ilmu Politik dan Komunikasi Volume VI No. 2 / Desember 2016

Rachmat, et. al. 2013 .Perumusan Kebijaksanaan Nilai Tukar Petani dan Komoditas Pertanian. Laporan Hasil Penelitian. Pusat Penelitian Sosial Ekonomi Pertanian. Depertemen Pertanian. Bogor. 